\title{
Purification and characterization of cysteine protease from miswak Salvadora persica
}

Wesam H. Abdulaal

\begin{abstract}
Background: Generally, proteases in medicinal plants had different therapeutic effects such as anti-inflammatory effect; modulate the immune response and inhibitory effect toward tumor growth. In this study, protease was purified and characterized from miswak roots, as medicinal plant and natural toothbrush.

Results: Physical and chemical characterization of cysteine protease P1 were studied such as pH optimum (6.5), optimum temperature $\left(50^{\circ} \mathrm{C}\right)$, thermal stability $\left(50^{\circ} \mathrm{C}\right)$ and $\mathrm{Km}(3.3 \mathrm{mg}$ azocasein/ml). The enzyme digested some proteins in the order of caseine $>$ haemoglobin > egg albumin > gelatin > bovine serum albumin. $\mathrm{Hg}^{2+}$ had strong inhibitory effect on enzyme activity compared with other metal ions. Kinetic of inhibition for determination the type of protease was studied. lodoactamide and p-Hydroximercuribenzaoic acid (p-HMB) caused strong inhibitory effect on enzyme activity indicating the enzyme is cysteine protease.
\end{abstract}

Conclusions: The biochemical characterization of this enzyme will be display the suitable conditions for using of this enzyme in toothpaste in the future and the enzyme may be used in other applications.

Keywords: Miswak, Salvadora persica, Cysteine protease, Purification, Characterization

\section{Background}

Proteases has been characterized from plants such as pea roots [1], ginger [2], Euphorbia microsciadia [3] and sweet potato [4]. Plant Proteases had medicinal properties such as bromelain proteases which treated anticancer and osteoarthritis [5-8]. Bromelain has also been effective in the treatment of cardiovascular diseases, where it inhibited the aggregation of blood platelet and minimized the risk of arterial thrombosis [9]. In human intestine, bromelain was absorbed without its degrading and losing its biological activity $[10,11]$. Other proteases from malian medicinal plants treated schistosomiasis [12]. Papaya proteases had pharmaceutical applications such as antitumorals, anti-inflammatory, wound healing and digestive disorder [13]. The partially purified protease from B. subtilis substantially dehaired cow skin [14].

Chemical compositions of miswak (Salvadora persica), natural toothbrush, included salvadoside and salvadoraside [15-17]. Silica removed stains from tooth surfaces $[17,18]$. Miswak had several biological activities such as oral hygiene, antibacterial and antifungal [17-21].
Previously, we published article on purification and characterization of $\alpha$-amylase from miswak [22]. In the present study, proteases from miswak has been purified and characterized.

\section{Methods \\ Miswak}

Miswak root was purchased from local market of Jeddah, Saudi Arabia.

\section{Measurement of protease used azocasein}

Proteolytic activity was measured by Dominguez and Cejudo [23]. One unit of protease was defined as $\mu$ g azocasein hydrolyzed $/ \mathrm{ml} / \mathrm{h}$ under standard assay conditions.

\section{Ninhydrin assay \\ $\alpha$-Amino nitrogen was determined by Moore [24] for the substrates gelatin, casein, egg albumin, bovine serum albumin and hemoglobin.}

\section{Measurement of protein}

Protein was measured by Bradford [25]. 


\section{Purification procedure of miswak protease}

Protease was purified from miswak root by using ion exchange and gel filtration chromatography techniques. By ion exchange, DEAE-Sepharose column $(10 \times 1.6 \mathrm{~cm}$. i.d.) was used and the elution buffer was Tris- $\mathrm{HCl} \mathrm{pH}$ 7.2 in presence of gradient of $\mathrm{NaCl}$ ranged from 0.0 to $0.3 \mathrm{M}$. The same buffer was used for gel filtration (Sephacryl S-200 column, $90 \times 1.6 \mathrm{~cm}$. i.d.) in absence of $\mathrm{NaCl}$.

\section{Molecular mass}

The molecular mass of purified protease was determined by two techniques, gel filtration and sodium dodecyl sulphate (SDS-PAGE) [26].

\section{Characterization}

Physical and chemical characterization of protease with respect to $\mathrm{pH}$ optimum ( $\mathrm{pH} 4-9)$, optimum temperature $\left(30-80^{\circ} \mathrm{C}\right)$, thermal stability $\left(30-80^{\circ} \mathrm{C}\right)$, substrate specificity (caseine, hemoglobin, egg albumin, gelatin and bovine serum albumin) and effect of metal ions $\left(\mathrm{Ca}^{2+}, \mathrm{Ni}^{2}\right.$ ${ }^{+}, \mathrm{Co}^{2+}, \mathrm{Pb}^{2+}, \mathrm{Hg}^{2+}, \mathrm{Cu}^{2+}$ and $\mathrm{Zn}^{2+}$ ) were studied. Kinetics of inhibition (phenylmethylsulfonyl fluoride (PMSF), 1,10 phenanthroline, ethylenediaminetetraacetic acid (EDTA), $p$-HMB and iodoacetamide) for determination the types of protease were carried out.

\section{Determination of $\mathrm{km}$}

The $\mathrm{km}$ values were determined from Lineweaver-Burk plots by using different concentrations of azocasein ranged from $1.5-4.5 \mathrm{mg} / \mathrm{ml}$ [27].

\section{Results}

Two chromatography columns were used for purification of protease from miswak. By DEAE-Sepharose column, three isoforms of proteases (P1, P2 and P3) were eluted by gradient steps of $\mathrm{NaCl}$ at $0.0,0.1$ and $0.2 \mathrm{M}$, respectively (Fig. 1). Protease P1 possessed the most activity (412 units) and the highest specific activity (89.5 units/mg protein) compared with the other isoforms (Table 1). Protease P1 was chromatographed on Sephacry S-200 column (Fig. 2), where the specific activity and fold purification raised to 355 units/mg protein and 9.1 fold, respectively. The homogeneity of protease P1 was detected by SDS-PAGE (Fig. 3). The molecular mass of protease P1 was found to be $42 \mathrm{kDa}$ by using Sephacryl S-200 and SDS-PAGE.

The substrate specificity of protease P1 was detected by using different proteins (Table 2). The protease P1 digested proteins in the order of caseine $>$ haemoglobin $>$ egg albumin $>$ gelatin $>$ bovine serum albumin with 100, 95, 72, 68 and 53\% residual activity, respectively. The kinetic of protease P1was detected by determining its $\mathrm{Km}$. The $\mathrm{Km}$ of protease P1 was found to be $3.3 \mathrm{mg}$ azocasein/ml by using reciprocal of Lineweaver-Burk plot (Fig. 4).

The effect of $\mathrm{pH}$ on the activity of protease $\mathrm{P} 1$ was determined (Fig. 5). The $\mathrm{pH}$ optimum of protease $\mathrm{P} 1$ was detected at $\mathrm{pH}$ 6.5. The enzyme acts on acidic and alkaline sides of $\mathrm{pH}$ profile, where its residual activity $\%$ was 45 and 38 at $\mathrm{pH} 4$ and 9, respectively. The temperature optimum of the protease P1 was determined from temperature profile (Fig. 6). The protease P1 had temperature optimum at $50^{\circ} \mathrm{C}$. The enzyme retained $40 \%$ of its activity at $80^{\circ} \mathrm{C}$. In the same manner, the protease $\mathrm{P} 1$ was thermal stable up to $50^{\circ} \mathrm{C}$ and the enzyme lost $50 \%$ of its activity at $80^{\circ} \mathrm{C}$ after incubation for $1 \mathrm{~h}$ (Fig. 7).

The effect of metal ions $\left(\mathrm{Ca}^{2+}, \mathrm{Ni}^{2+}, \mathrm{Pb}^{2+}, \mathrm{Co}^{2+}\right.$, $\mathrm{Cu}^{2+}$ and $\mathrm{Zn}^{2+}$ ) on the activity of the protease $\mathrm{P} 1$ was detected (Table 3). All metal ions caused partial inhibitory effect on the protease P1 except of $\mathrm{Hg}^{2+}$

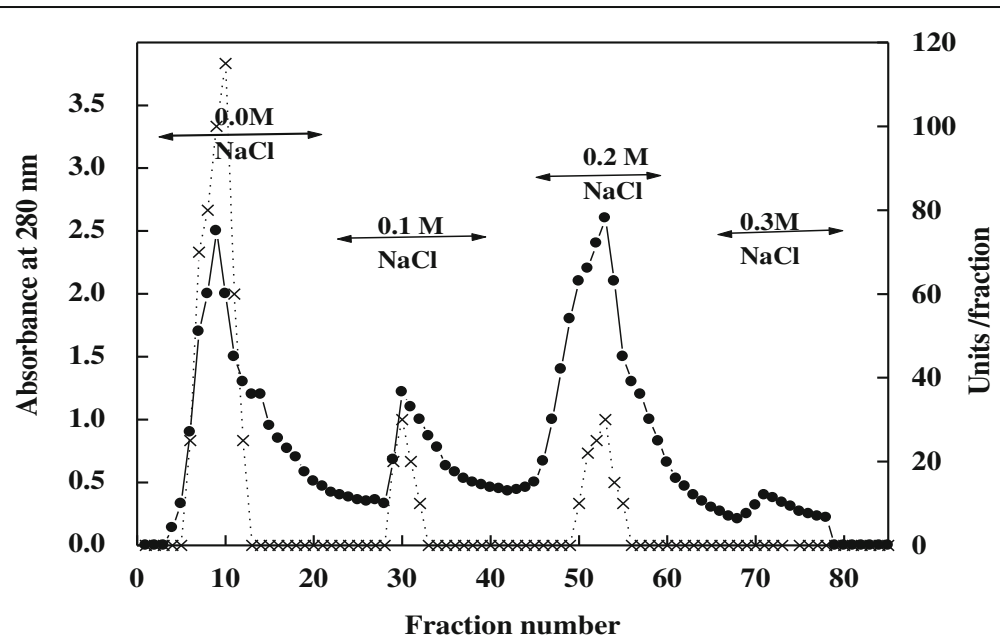

Fig. 1 Chromatography of miswak protease on DEAE-Sepharose column. (•-) Absorbant at $280 \mathrm{~nm},(\mathrm{x}-\mathrm{x})$ units/fraction 
Table 1 Purification scheme for meswak protease

\begin{tabular}{llllll}
\hline Steps & T. units & T. Protein mg & S.A & Fold purification & Recovery $100 \%$ \\
\hline Crude extract & 545 & 14 & 39 & 1 & 100 \\
Chromatography on DEAE-Sepharose & & & & \\
$0.0 \mathrm{M} \mathrm{NaCl}(\mathrm{P} 1)$ & 412 & 4.6 & 89.5 & 2.29 & 75 \\
$0.1 \mathrm{M} \mathrm{NaCl}(\mathrm{P} 2)$ & 40 & 2.2 & 18 & 0.46 & 7.3 \\
$0.2 \mathrm{M} \mathrm{NaCl}(\mathrm{P} 3)$ & 60 & 6.5 & 9.2 & 0.23 & 11 \\
Sephacryl S-200 P1 & 355 & 1.0 & 355 & 9.1 & 65 \\
\hline
\end{tabular}

${ }^{a}$ S.A Specific activity (units/mg protein)

which caused strong inhibitory effect. The study of protease inhibitors on the activity protease P1 was evaluated (Table 4). PMSF, 1,10 phenanthroline and EDTA caused slightly inhibitory effect on the activity protease $\mathrm{P} 1$, while $p$-HMB and iodoacetamide caused strong inhibitory effect.

\section{Discussion}

In this study, protease was purified and characterized from miswak roots. After two steps of chromatography, the homogeneity of protease P1 was detected by SDS-PAGE. The molecular mass of protease P1 was found to be $42 \mathrm{kDa}$. Different molecular weights (30-45
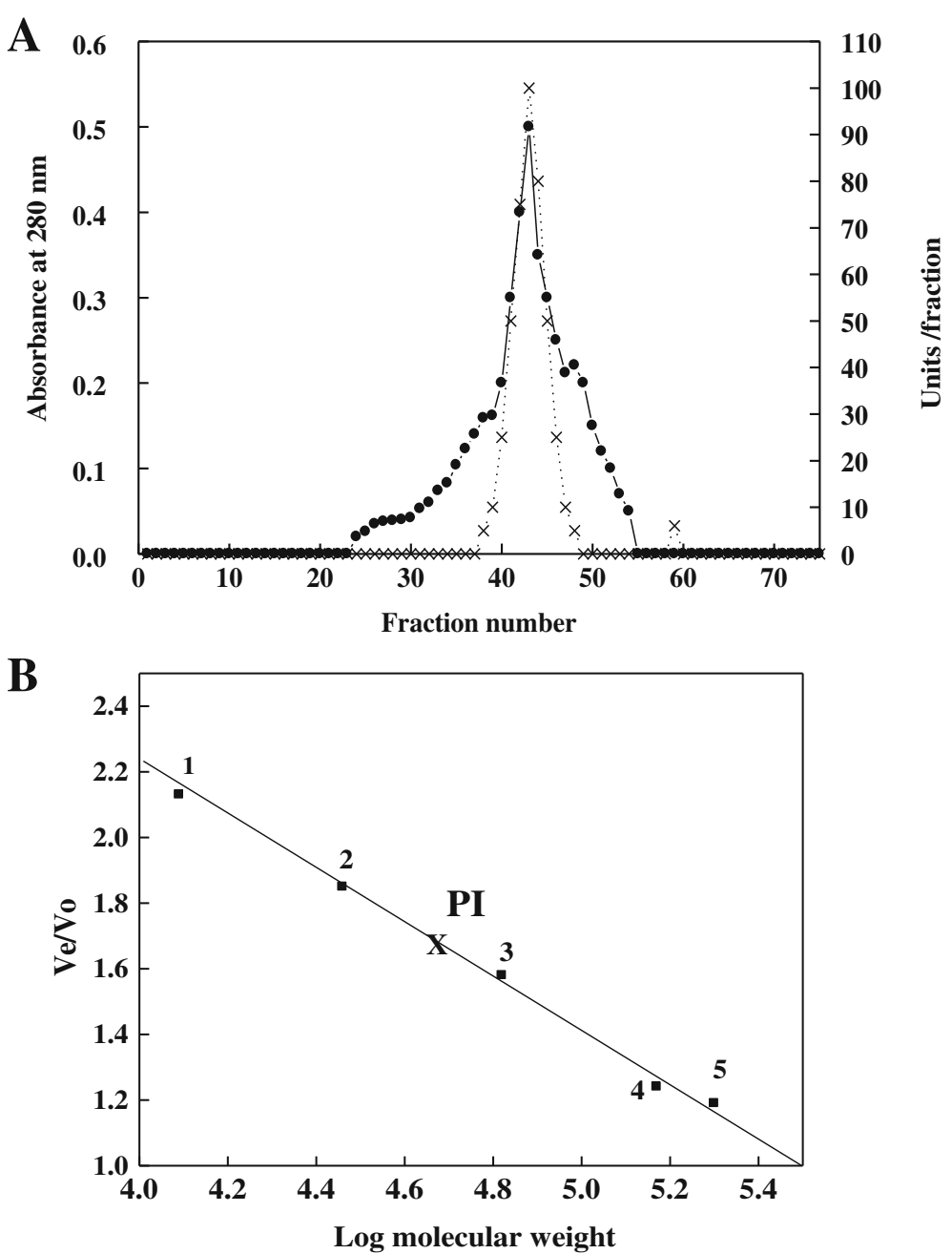

Fig. 2 a Chromatography of miswak protease P1 DEAE-Sepharose fraction on Sephacryl S-200 column. (•- - •) Absorbant at 280 nm, (x - x) units/ fraction. b Molecular weight value for miswak protease P1 was calculated from calibration curve of Sephacryl S-200 column. Standard proteins from 1 to 5 were 1) Cytochrome C (12,400 Da); 2) Carbonic anhydrase (29,000 Da); 3)Bovine albumin (66,000 Da); 4)Alcohol dehydrogenase (150,000 Da); 5) $\beta$-Amylase (200,000 Da). Void volume was determined with Dextran blue (2000, $000 \mathrm{Da})$ 


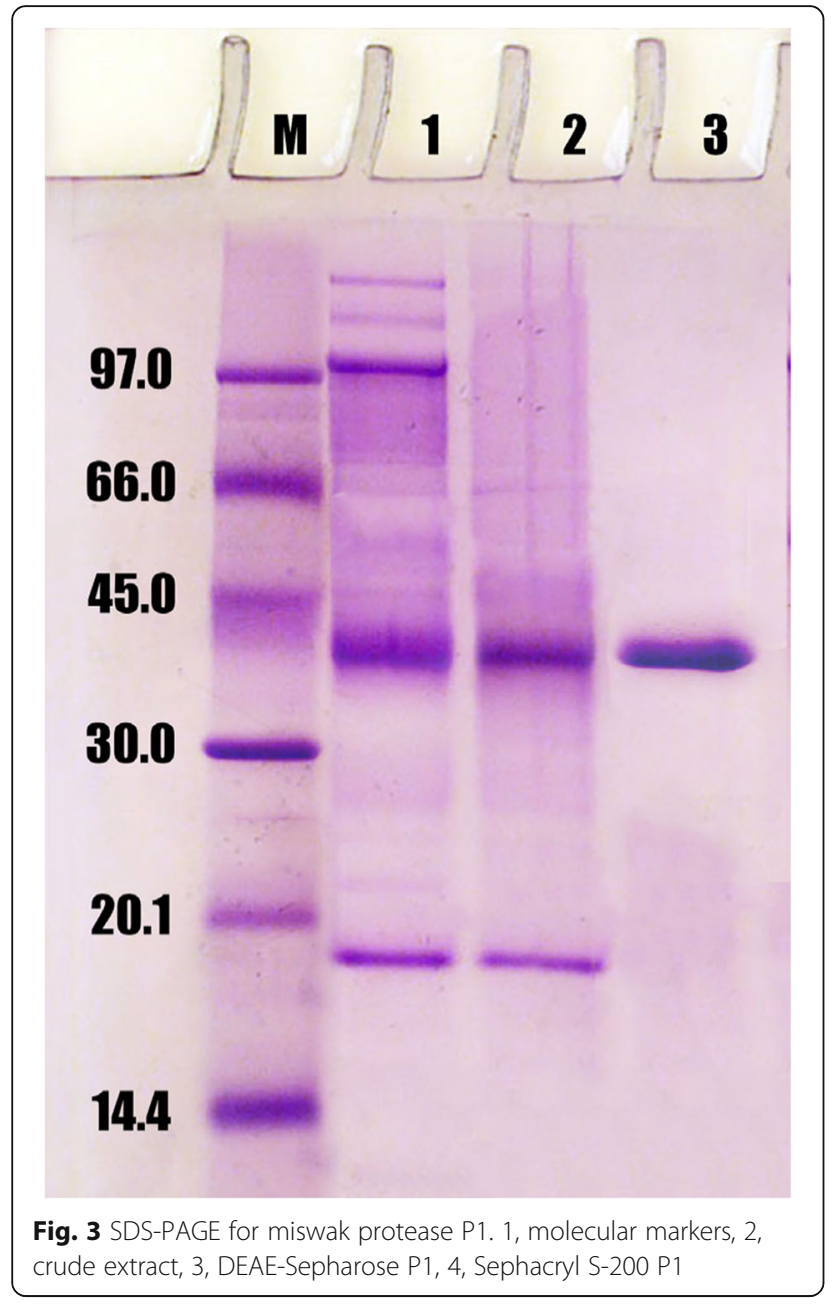

$\mathrm{kDa}$ ) were detected for cysteine proteases from horse gram [28], Curcuma longa [29], Euphorbia nivulia [30] and ginger rhizome [31].

The substrate specificity of protease P1 showed that the enzyme acted on caseine, haemoglobin, egg albumin, gelatin and bovine serum albumin. Similar digestion was detected for horse gram cysteine protease toward the substrates [28]. The $\mathrm{Km}$ of protease P1 was found to be $3.3 \mathrm{mg}$ azocasein $/ \mathrm{ml}$. Similar $\mathrm{Km}(2.8 \mathrm{mg}$ azocasein $/ \mathrm{ml})$ was detected in germinated wheat cysteine protease [32].

Table 2 Substrate specificity of miswak protease P1. Each value represents the mean of three experiments \pm S.E

\begin{tabular}{lll}
\hline Substrate & Units/mg protein & Relative activity \% \\
\hline Casein & $370 \pm 18.5$ & $100 \pm 5.0$ \\
haemoglobin & $350 \pm 16.9$ & $95 \pm 4.6$ \\
Egg albumin & $264 \pm 13.9$ & $72 \pm 3.8$ \\
Gelatin & $348 \pm 20.4$ & $68 \pm 4.0$ \\
Bovine serum albumin & $197 \pm 10.4$ & $53 \pm 2.8$ \\
\hline
\end{tabular}

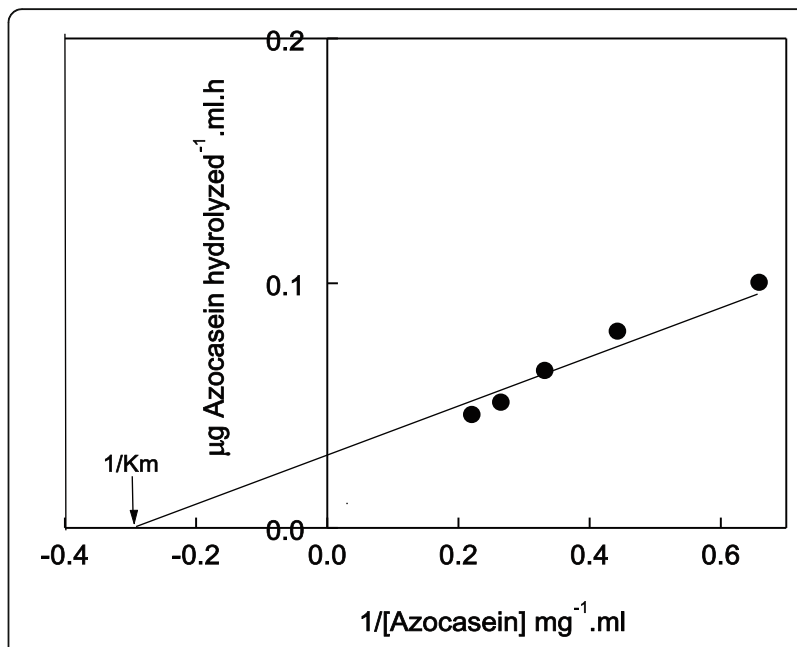

Fig. 4 Reciprocal of Lineweaver-Burk plot relating miswak protease P1 reaction velocities to azocasein concentrations (1.5-4.5 mg). Km was calculated as mg azocasein/ml

The high value of $\mathrm{Km}(6.74 \mathrm{mg}$ azocasein/ml) was detected for onion [33].

The maximum activity of protease P1 was detected at $\mathrm{pH}$ 6.5. However, horse gram cysteine protease showed higher activity at pH 5.5 [28]. The acidic pH optimum of germinated wheat cysteine protease was detected at 4.0 [32]. The protease P1 had temperature optimum at $50^{\circ}$ $\mathrm{C}$ and thermal stability up to $50^{\circ} \mathrm{C}$. The maximum activity of cysteine proteases from horse gram and Euphorbia microsciadia was detected at $40^{\circ} \mathrm{C}$ and $45^{\circ} \mathrm{C}$, respectively $[3,28]$.

All metal examined caused partial inhibitory effect on the protease P1. However, the inhibitory effect of $\mathrm{Hg}^{2+}$

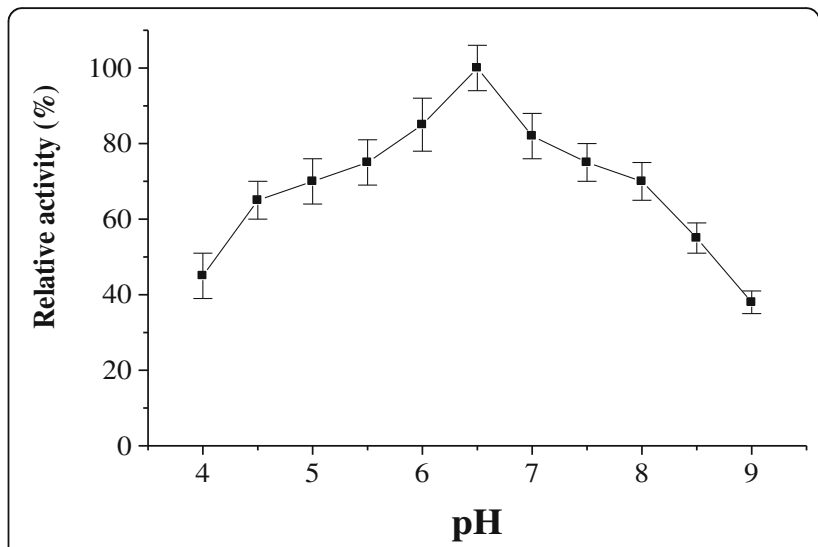

Fig. $5 \mathrm{pH}$ optimum of miswak protease P1. The reaction mixture contained in $1.0 \mathrm{ml}$ : $3 \%$ azocasein, $100 \mu \mathrm{l}$ of enzyme and $50 \mathrm{mM}$ sodium acetate buffer ( $\mathrm{pH} 4.0-6.5)$, and $50 \mathrm{mM}$ Tris-HCl buffer (pH 7.0-9.0) and adjusted to $1 \mathrm{ml}$ with distilled water. Each point represents the mean of three experiments \pm S.E 


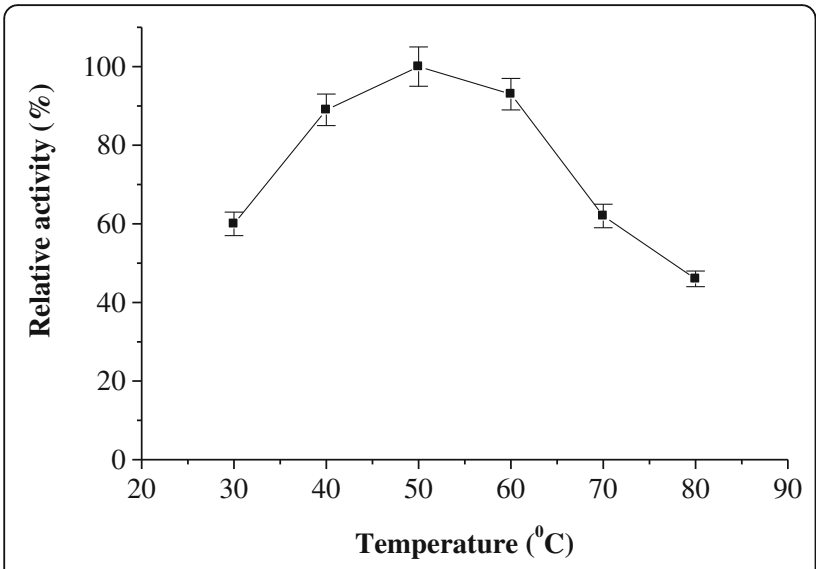

Fig. 6 Temperature optimum of miswak protease P1. The enzyme activity was measured at various temperatures $\left(30-80^{\circ} \mathrm{C}\right)$ using the standard assay method. Each point represents the mean of three experiments \pm S.E

was strong indicated that the protease P1 is cystein protease. This agreed with cysteine proteases from $E u$ phorbia microsciadia and horse gram which inhibited by $\mathrm{Hg}^{2+}[3,28]$. The inhibition of the activity of protease P1 by protease inhibitors determined the types of protease. The slightly inhibitory effect of PMSF, 1,10 phenanthroline and EDTA on the activity of protease P1 showed that the enzyme did not serine or metaloprotease. $p$-HMB and iodoacetamide caused strong inhibitory effect on the activity of the protease P1 indicating the enzyme is cysteine protease. Similar

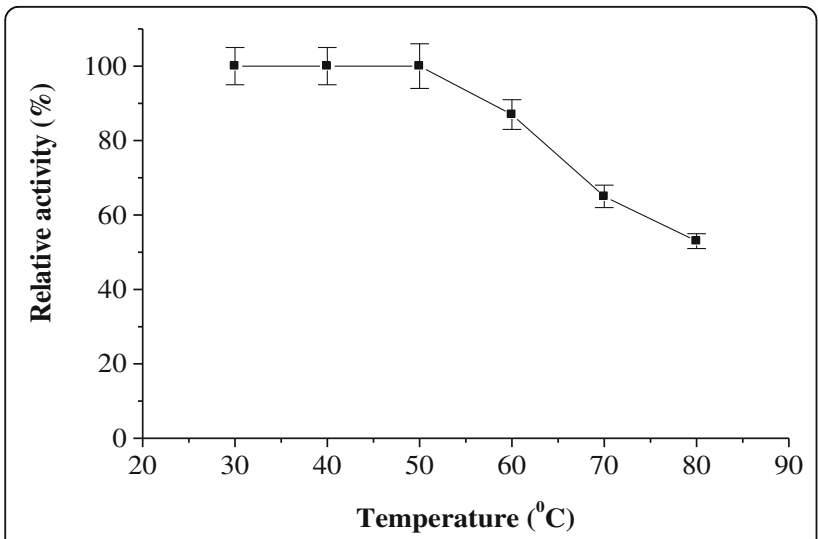

Fig. 7 Effect of temperature on the thermal stability of miswak protease $\mathrm{P} 1$. The reaction mixture contained in $1.0 \mathrm{ml}: 3 \%$ azocasein, $100 \mu \mathrm{l}$ of enzyme and $50 \mathrm{mM}$ sodium acetate buffer 6.5 and adjusted to $1 \mathrm{ml}$ with distilled water. The reaction mixture was preincubated at various temperatures for 15 min prior to substrate addition, followed by cooling in an ice bath. The enzyme activity was measured using the standard assay method. Activity at zero time was taken as 100\% activity. Each point represents the mean of three experiments \pm S.E
Table 3 Influence of metal ions at $5 \mathrm{mM}$ on miswak protease P1. Each value represents the mean of three experiments \pm S.E

\begin{tabular}{lll}
\hline Metal cations & Units/mg protein & Relative activity \% \\
\hline Control & $355 \pm 12.4$ & $100 \pm 3.5$ \\
$\mathrm{Ca}^{2+}$ & $286 \pm 15.0$ & $80 \pm 4.2$ \\
$\mathrm{Ni}^{2+}$ & $293 \pm 13.5$ & $82 \pm 3.8$ \\
$\mathrm{~Pb}^{2+}$ & $347 \pm 16.4$ & $97 \pm 4.6$ \\
$\mathrm{Co}^{2+}$ & $286 \pm 11.7$ & $80 \pm 3.3$ \\
$\mathrm{Hg}^{2+}$ & $164 \pm 9.2$ & $46 \pm 2.6$ \\
$\mathrm{Cu}^{2+}$ & $268 \pm 14.6$ & $75 \pm 4.1$ \\
$\mathrm{Zn}^{2+}$ & $272 \pm 12.8$ & $76 \pm 3.6$ \\
\hline
\end{tabular}

inhibitory effects were detected for cysteine proteases from Euphorbia microsciadia [3], horse gram [28] and ginger rhizome [31].

From the above findings the miswak protease P1, as cysteine protease, could be used in toothpaste for oral hygiene. However, Pleszczyńska et al. [34] studied the potential applications of enzymes in the treatment and prevention of oral diseases. Proteases of plant origin have been tested for removal of tooth stains and calculus [35]. A papain, as cysteine protease, gel has been used for removal of caries, which eliminates infected dentin and simultaneously preserves a healthy dental structure [36].

\section{Conclusions}

The study indicated that the purified miswak protease P1 is cysteine protease depending on the study of the inhibition by cysteine protease inhibitors and $\mathrm{Hg}^{2+}$. Depending on cysteine proteases such as papain are used in oral gel, miswak protease P1may be digested the protein residues in the oral when the miswak is used as natural toothbrush. The biochemical characterization of this enzyme will be display the suitable conditions for using this enzyme in toothpaste in the future and the enzyme may be used in other applications.

Table 4 Effect of protease inhibitors at $2 \mathrm{mM}$ on miswak protease P1. Each value represents the mean of three experiments \pm S.E

\begin{tabular}{lll}
\hline Substrate & Units/mg protein & Relative activity \% \\
\hline Control & $321 \pm 17.3$ & $100 \pm 5.4$ \\
PMSF & $289 \pm 13.4$ & $90 \pm 4.2$ \\
1,10 Phenathroline & $304 \pm 13.1$ & $95 \pm 4.1$ \\
EDTA & $293 \pm 12.5$ & $91 \pm 3.9$ \\
p-HMB & $71 \pm 3.8$ & $22 \pm 1.2$ \\
lodoacetamide & $118 \pm 5.1$ & $35 \pm 1.5$ \\
\hline
\end{tabular}




\section{Abbreviations}

EDTA: Ethylenediaminetetraacetic acid; $p$-HMB: $p$-Hydroximercuribenzaoic acid; PMSF: Phenylmethylsulfonyl fluoride; SDS-PAGE: Sodium dodecyl sulphate

\section{Acknowledgements}

Not Applicable.

\section{Funding}

This project was funded by the Deanship of Scientific Research (DSR) at King Abdulaziz University, Jeddah, under grant No. (G-204-130-438). The author, therefore, acknowledge with thanks DSR for technical and financial support.

\section{Availability of data and materials}

All data generated or analyzed during this study are included in this published article or available from the corresponding author on reasonable request.

\section{Authors' contributions}

WA designed the experiments, analyzed the data and approved the final version of the manuscript.

\section{Ethics approval and consent to participate}

Not Applicable.

\section{Consent for publication}

Not Applicable.

\section{Competing interests}

The author declares that he has no competing interests.

\section{Publisher's Note}

Springer Nature remains neutral with regard to jurisdictional claims in published maps and institutional affiliations.

Received: 9 September 2018 Accepted: 22 November 2018

Published online: 03 December 2018

\section{References}

1. Vincent $\mathrm{J}$, Brewin NJ. Immunolocalization of a cysteine protease in vacuoles, vesicles, and symbiosomes of pea nodule cells. Plant Physiol. 2000; 123:521-30.

2. Kim M, Hamilton SE, Guddat LW, Overall CM. Plant collagenase: unique collagenolytic activity of cysteine proteases from ginger. Biochim Biophys Acta. 2007;1770:1627-35.

3. Rezanejad H, Karbalaei-Heidari HR, Rezaeia S, Yousefi R. Microsciadin, a new milk-clotting cysteine protease from an endemic species, Euphorbia microsciadia. Biom J. 2015;1:93-103.

4. Huang DJ, Chen HJ, Hou WC, Chen TE, Hsu WY, Lin YH. Expression and function of a cysteine proteinase cDNA from sweet potato (Ipomoea batatas [L.] Lam Tainong 57') storage roots. Plant Sci. 2005;169:423-31.

5. Brien S, Lewith G, Walker A, Hicks SM, Middleton D. Bromelain as a treatment for osteoarthritis: a review of clinical studies. Evid Based Complement Alternat Med. 2004;1:251-25.

6. Gerard G. Anticancer treatment and bromelain. Agressologie. 1972;4:261-74.

7. Grabowska E, Eckert K, Fichtner I, Schulze-Forster K, Maurer H. Bromelain proteases suppress growth invasion and lung metastasis of B16F10 mouse melanoma cells. Int J Oncol. 1997;11:243-8.

8. Pavan R, Jain S, Shraddha, Kumar A. Properties and therapeutic application of Bromelain. Biotechnol Res Int. 2012;2012:976203. https://doi.org/10.1155/ 2012/976203.

9. Heinicke RM, van der Wal L, Yokoyama M. Effect of bromelain (Ananase) on human platelet aggregation. Experientia. 1972;28:844-5.

10. Chobotova K, Vernallis AB, Majid FAA. Bromelain's activity and potential as an anti-cancer agent: current evidence and perspectives. Cancer Lett. 2010; 290:148-56.

11. Castell JV, Friedrich G, Kuhn CS, Poppe GE. Intestinal absorption of undegraded proteins in men: presence of bromelain in plasma after oral intake. Am J Phys. 1997;273:G139-46.

12. Bah S, Paulsen BS, Diallo D, Johansen HT. Characterization of cysteine proteases in Malian medicinal plants. J Ethnopharmacol. 2006;107:189-98.
13. Chaiwut P, Pintathong P, Rawdkuen S. Extraction and three-phase partitioning behavior of proteases from papaya peels. Process Biochem. 2010;45:1172-5

14. Hakim A, Bhuiyan FR, labal A, Emon TH, Ahmed J, Azad AK. Production and partial characterization of dehairing alkaline protease from Bacillus subtilis AKAL7 and Exiguobacterium indicum AKAL11 by using organic municipal solid wastes. Heliyon. 2018;4:e00646. https://doi.org/10.1016/j.heliyon.2018. e00646.

15. Kamel M, Ohtani K, Assaf M. Lignan glycosides from stems of Salvadora persica. Phytochem. 1992;31:2469-71.

16. Abdel-Wahab S, Selim M, El-Fiki N. Investigation of the flavonoid content of Salvadora persica L. Bull Fac Pharm Cairo Univ. 1990;28:67-70.

17. Al-Lafi T, Ababneh $\mathrm{H}$. The effect of the extract of the miswak (chewing sticks) used in Jordan and the Middle East on oral bacteria. Int Dent J. 1995; 45:218-22.

18. Khoory T. The use of chewing sticks in preventive oral hygiene. Clin Prev Dent. 1983:5:11-4.

19. Al-Bagieh NH, Idowu A, Salako NO. Effect of aqueous extract of miswak on the in vitro growth of Candida albicans. Microbios. 1994;80:107-13.

20. Almas K. The effect of Salvadora persica extract (miswak) and chlorahexidine gluconate on human dentin: a SEM study. J Contemp Dent Prac. 2002;3:1-10.

21. Sofrata A, Lingstrm P, Baljoo M, Gustafsson A. The effect of miswak extract on plaque pH. An in vivo study. Caries Res. 2007;41:451-4.

22. Mohamed SA, Almulaiky YQ, Ahmed YM, Al-Bar OAM, Ibrahim HI. Purification and characterization of a-amylase from Miswak Salvadora persica. BMC Complement Altern Med. 2014:14:119.

23. Dominguez F, Cejudo FJ. Characterization of the endoproteases appearing during wheat grain development. Plant Physiol. 1996;112:1211-7.

24. Moore S. Amino acid analysis: aqueous dimethyl sulfoxide as solvent for the ninhydrin reaction. J Biol Chem. 1968:243:6281-3.

25. Bradford MM. A rapid and sensitive method for the quantitation of microgram quantities of protein using the principle of protein-dye binding. Anal Biochem. 1976;72:248-54

26. Laemmli UK. Cleavage of structural proteins during the assembly of the head bacteriophage T4. Nature. 1970;227:680-5.

27. Lineweaver H, Burk D. The determination of enzyme dissociation constants. J Am Chem Soc. 1934:56:658-66.

28. Jinka R, Ramakrishna V, Rao SK, Rao RP. Purification and characterization of cysteine protease from germinating cotyledons of horse gram. BMC Biochem. 2009;10:28

29. Badgujar SB, Mahajan RT. Comparison of cysteine proteases of four laticiferous plants and characterization of Euphorbia nivulia Buch.Ham. Latex glycosylated cysteine peptidase. Indian J Nat Prod Resour. 2012;3:152-60.

30. Nagarathnam R, Rengasamy A, Balasubramanian R. Purification and properties of cysteine protease from rhizomes of Curcuma longa (Linn.). J Sci Food Agric. 2010;90:97-105.

31. Hashim MM, Mingsheng D, Iqbal MF, Xiaohong C. Ginger rhizome as a potential source of milk coagulating cysteine protease. Photochem. 2011;72: 458-64

32. Fahm AS, Ali AA, Mohamed SA. Characterization of a cysteine protease from wheat Triticum aestivum (cv. Giza 164). Bioresour Technol. 2004;91:297-304.

33. Ndidi US, Nzelibe HC. Purification and characterization of a cysteine protease from the bulb of common onion Allium cepa L. (cv. Red creole). Int J Modern Biochem. 2012;1:1-17.

34. Pleszczyńska M, Wiater A, Bachanek T, Szczodrak J. Enzymes in therapy of biofilm-related oral diseases. Biotechnol Appl Biochem. 2017;64:337-46.

35. Joiner A. Whitening toothpastes: a review of the literature. J Dent. 2010:38 e17-24.

36. Bussadori SK, Castro LC, Galvão AC. Papain gel: a new chemo-mechanical caries removal agent. J Clin Pediatr Dent. 2005;30:115-9. 